\title{
UNSUR LATAR BELAKANG DALAM KARYA SASTRA
}

\author{
Asruni Samad \\ Fakultas Sastra, Universitas Muslim Indonesia \\ Jalan Urip Sumoharjo KM 5, Makassar \\ asrunysamad1198@gmail.com
}

\begin{abstract}
Abstrak
Latar belakang adalah suatu dasar atau titik tolak yang memberikan pemahaman kepada pembaca maupun pendengar mengenai beberapa kumpulan informasi yang telah disusun secara terstruktur dan sistematis oleh seorang penulis. Latar belakang harus saling berkesinambungan dengan masalah yang dihadapi oleh penulis terhadap karya yang ditulisnya. Oleh karena itu latar belakang yang baik dan benar adalah latar belakang yang memiliki alasan yang menurut pikiran dan pertimbangan yang logis atau bisa juga disertakan data atau fakta yang mendukung. Penulis harus mencantumkan referensi mengenai karya tulisnya sehingga tidak ada kesamaan dengan tema yang telah digunakan penulis yang lain. Bagi pembaca dan pendengar latar belakang sendiri menjadi sebuah dasar yang dibutuhkan, karena jika pembaca sudah membaca latar belakang suatu karya tulis maka mereka akan mengetahui apa isi dari karya tulis tersebut. Kelebihan dicantumkannya latar belakang adalah pembaca mengetahui apa yang diteliti oleh penulis tersebut.
\end{abstract}

Kata Kunci: Latar belakang, karya sastra

\section{PENDAHULUAN}

Hakikat latar yaitu sebagai sebuah cerita fiksi, seperti kita berhadapan dengan sebuah dunia yang sudah dilengkapi dengan para tokoh penghuni lengkap dengan berbagai permasalahan hidupnya. Namun, hal itu kurang lengkap sebab tokoh dengan berbagai pengalaman kehidupan itu memerlukan landas tumpu, tempat dan waktu serta aturan kehidupan bermasyarakat sebagaimana halnya kehidupan manusia di dunia nyata. Dengan kata lain fiksi sebagai sebuah dunia, disamping membutuhkan tokoh, cerita, dan plot juga butuh latar. Latar atau setting yang disebut juga sebagai landas tumpu, menunjuk pada pengertian tempat, hubungan waktu sejarah, dan lingkungan sosial tempat terjadinya peristiwaperistiwa yang diceritakan (Abrams, 1999:284).
Latar memberikan pijakan cerita secara konkret dan jelas. Hal ini penting untuk kesan realistis kepada pembaca, menciptakan suatu suasana tertentu yang seolah-olah sungguh-sungguh ada dan terjadi. dengan demikian, pembaca merasa difasilitas dan dipermudah untuk "mengoperasikan" daya imajinasinya, disamping dimungkinkan untuk perperan serta secara kritis sehubung dengan pengetahuannya tentang latar.

\section{PEMBAHASAN}

Penulisan fiksi didukung oleh latar. sebagai sebuah karya yang menggambarkan kehidupan yang seolaholah nyata maka sebuah tulisan fiksi harus mempertimbangkan latar kejadianya cerita. Latar harus benar-benar mendukung isi cerita seolah-olah suatu cerita objektif. Latar atau setting keterangan tentang 
waktu, ruang dan suasana terjadinya lakuan dalam sastra (Sudjiman, 1986:46).

Menurut Hartoko dan Rahmanto (1986:78), latar merupakan penempatan ruang dan waktu, seperti yang terjadi pada karya naratif dan dramatik. Brooks (dalam tarigan, 1986:136) menyebutkan bahwa latar terdiri atas latar belakang fisik, unsur tempat, dan ruang dalam sebuah cerita. Abrams (1981:175) menyatakan bahwa latar adalah dasar pijakan yang mengacu pada tempat, hubungan waktu, dan lingkungan sosial tempat terjadinya peristiwa-peristiwa yang diceritakan.

Sementara itu, Chatman (1980:101103) mengemukakan bahwa dimensi waktu berkaitan dengan peristiwa-peristiwa yang membentuk alur, sedangkan dimensi ruang berkaitan dengan tokoh-tokoh cerita. seperti lingkungan hidup, sosial, dan adat istiadat. Ruang terjadinya peristiwa dapat mencakup lingkungan yang bersifat geografis, seperti kota, desa, rumah, pabrik, gedung sekolah, dan sebagainya. Selain itu dapat mencakup kebiasaan, cara berfikir, dan norma kehidupan yang berlaku dalam kehidupan sekelompok orang.

Penokohan dan latar memiliki hubungan erat yang bersifat timbal balik. Dalam banyak hal, sifat latar akan mempengaruhi pribadi tokoh. Dengan kata lain, kepribadian seorang tokoh dibentuk oleh keadaan latarnya, seperti pribadi atau sifat orang kota akan berbeda dengan orang desa atau mereka yang tinggal di pedalaman. Dalam kaitannya dengan penjelasan itu, novel Saman akan dianalisis berdasarkan latar ruang dan latar waktu.

\section{Latar Fisik Dan Latar Spiritual}

Membaca sebuah novel kita akan bertemu dengan lokasi tertentu seperti nama kota, desa, jalan, hotel, penginapan, kamar, dan lain-lain tempat terjadinya peristiwa. Di samping itu kita juga akan berurusan dengan hubungan waktu seperti tahun, tanggal, pagi, siang, malam, pukul, saat bulan purnama, saat hujan gerimis, di awal bulan, atau kejadian yang menyaran pada waktu tipikal tertentu, dan sebagainya. karena latar terdapat secara jelas menunujuk pada lokasi tertentu, yang dapat dilihat dan dirasakan kehadirannya, disebut sebagai latar fisik (physical setting).

Keadaan yang agak berbeda adalah latar yang behubungan dengan waktu. Latar waktu jelas tidak dapat dilihat, namun bekas-bekas kejadiannya dapat dilihat pada tempat-tempat tertentu berdasarkan sarkan waktu kesejaraannya. Keadaan tempat tertentu yang antara lain ditandai oleh bangunan fisik, pada umumnya tidak sama, dan itu disebabkan oleh waktu. Maka, pelukisan tempat dapat berubah tergantung kapan ia dilukiskan. Misalnya Yogyakarta tahun 1945 jelas tidak sama dengan Yogyakarta tahun 1995 atau 2015.

Perbedaan itu lebih disebabkan oleh adanya perbedaan waktu yang terkait erat dengan pembangunan fisik. Walau orang mungkin berkeberatan, tampaknya latar waktu lebih dekat kelatar fisik sebab adanya perubahan-perubahan fisik disebuah tempat dalam banyak terkait dengan waktu. Penunjukkan latar fisik dalam teks fiksi dapat dengan cara yang bermacam-macam tergantung selera dan kreativitas pengarang.

Ada pengarang yang melukiskan secara rinci, dan sebaliknya ada pula yang sekedar menunjukkan dalam bagian cerita. Artinya ia tidak secara khusus menceritakan situasi latar. Latar sebuah cerita fiksi kadang-kadang menawarkan berbagai kemungkinan yang justru dapat 
lebih menjangkau diluar makna cerita itu sendiri. Berbagai elemen latar yang ditampilkan dengan sifat-sifat kekhasannya menawarkan kemungkinan-kemungkinan lain. misalnya, kemungkinan adanya temu budaya, baik budaya dalam lingkungan nasional, budaya antardaerah, maupun lingkup internasional, budaya antar bangsa.

\section{Latar Netral dan Latar Fungsional}

Latar sebuah cerita fiksi barangkali hanya berupa latar yang sekedar sebagai latar, karena sebuah cerita memang membutuhkan landas tumpu, pijakan. sebuah nama tempat hanya sekedar sebagai tempat terjadinya peristiwa yang diceritakan, tidak lebih dari itu. Jika disebut nama sebuah kota misalnya Yogyakarta, itu sekedar sebagai kota yang mungkin disertai dengan sifat umum sebuah kota yang bersangkutan. Jika disebutkan nama jalan, misalnya Malioboro, ia sekedar sebagai jalan raya yang mungkin disertai deskripsi sifat umum sebuah jalan raya, atau mungkin sekadar disebut saja. Latar sebuah karya yang hanya bersifat demikian disebut sebagai latar netral (neutral setting).

Latar Netral tidak memiliki dan tidak mendeskipsikan sifat khas tertentu yang menonjol yang terdapat dalam sebuah latar sesuatu yang justru dapat membedakannya dengan latar-latar lain. Sifat yang dituntunjukkan tersebut lebih merupakan sifat umum terhadap hal yang sejenis, misalnya desa, kota, hutan, pasar, sehingga sebenarnya hal itu dapat berlaku dimana saja. Artinya jika tempat-tempat tersebut dipindahkan (baca: diganti namannya), hal itu tidak akan memengaruhi pemlotan dan penokohan.

Hal yang sama juga dapat dapat berlaku untuk latar waktu dan sosialbudaya. Dalam latar netral kadang-kadang bahkan kita tidak tahu pasti cerita terjadi dimana, kapan, dan lingkungan sosialbudaya yang mana. Dengan demikian, latar tidak bersifat fungsional, tidak terjalin secara koherensif dengan berbagai unsur fiksi yang lain. Namun, hal itu tidak harus berarti melemahkan karya fiksi bersangkutan. Mungkin sekali pengarang sengaja tidak berniat menonjolkan unsur latar dalam karyanya itu, melainkan lebih menekankan unsur yang khususnya alur (fiksi: aluran) atau tokoh (fiksi: tokohan).

Latar Fungsional. latar fungsional dipihak lain, memiliki dan menonjolkan sifat khas latar tertentu, baik yang menyangkut unsur tempat, waktu maupun sosial-budaya. Jika membaca Pengakuan Pariem Sri Sumarah atau Para Priyayi misalnya kita akan merasakan dominannya lingkungan sosial masyarakat jawa, hanya masyarakat jawa dan tidak dapat untuk masyarakat yang lain, dengan tempat di jawa (Yogjakarta) pula. Latar sosial (dan tempat) karya-karya tersebut, dengan demikian bersifat tipikal.

Latar fungsional adalah unsur latar yang yang memiliki fungsi menonjol dalam kaitan dengan cerita secara keseluruhan. Latar fungsional adalah latar yang mampu memengaruhi dan bahkan ikut menentukan perkembangan plot dan pembentukan karakter tokoh. Seorang tokoh memiliki karakter tertentu misalnya Sastrodarsono (Para Priyayi) karena dibentuk oleh latar, tepatnya latar spiritual Jawa, yang membesarkannya. Karena memengaruhi perkembangan plot dalam sebuah cerita fiksi, latar fungsional tidak dapat diganti dengan latar lain tanpa mengganggu atau bahkan merusak cerita.

Adanya deskripsi latar spiritual, dikemukakan diatas pada umumnya menyebabkan sebuah karya menjadi khas, spesifik, fungsional dan tipikal. Hal itulah 
yang justru menunjukkan dan menandai kekhasan sebuah latar dan sekaligus membedakannya dengan latar-latar yang lain. Tiap daerah dan lingkungan sosialbudaya yang berbeda, dalam banyak hal, akan mimiliki konvensi dan nilai-nilai spiritual yang berbeda pula.

Deskripsi Latar Spiritual sebuah latar justru dilakukan dengan menekankan adanya perbedaan itu sehingga latar memang menjadi khas, tipikal, misalnya deskripsi sesuatu yang mencerminkan warna setempat, warna lokal. Deskripsi warna lokal juga dapat diperkuat dengan pelukisan keadaan geografis setempat, latar fisik, yang juga khas yang barang kali berwujud landmark. Latar tipikal biasanya mencerminkan "latar" tertentu di dunia nyata, atau paling tidak, kita dapat menafsirkan demikian. Oleh karena itu, latar tipikal biasanya digarap secara teliti dan hati-hati oleh pengarang, yang antara lain dimaksudkan untuk mengesani pembaca agar karya itu tampak realistik, terlihat sungguh-sungguh diangkat dari kondisi faktual.

\section{Penekanan Unsur Latar}

Perbedaan antara latar netral dan latar fungsional, juga latar tipikal, sebenarnya juga berarti mempersoalkan penakanan masalah latar. Latar netral menyaran pada kurangnya penekanan unsur latar, sebaliknya latar fungsional dan atau latar tipikal pada adanya penekanan unsur latar. Membaca beberapa buah karya fiksi sering kita rasakan adanya perbedaan peranan latar itu. Pada karyakarya tertentu tampak latar sekedar dipergunakan sebagai tempat pijakan berlangsungnya cerita saja. Sebaliknya, pada karya-karya yang lain latar mempunyai peranan dalam pengembangan cerita, latar tampak mendapat penekanan.
Penekanan latar pun dapat mencakup ketiga unsur sekaligus atau hanya satu-dua unsur saja.

Unsur latar yang ditekankan perannya dalam sebuah novel, langsung atau tidak langsung, akan berpengaruh terhadap elemen fiksi yang lain, khususnya alur dan tokoh. Jika elemen tempat mendapat penekanan dalam sebuah novel, ia akan dilengkapi dengan sifat khas keadaan geografis setempat yang mencirikannya, yang disebut sebagai landmark, yang berbeda dengan tempattempat yang lain kekhasan geografis setempat misalnya desa, kota, pelosok pedalaman, daerah pantai, mau tidak mau akan berpengaruh terhadappenokohan dan pemlotan. Artinya tokoh dan alur dapat menjadi lain jika latar tempatnya berbeda. Penekanan latar tempat banya dijumpai pada karya yang berlatar daerah misalnya Upacara karya Korrie Layun Rampang yang berlatar di pedalaman Kalimantan.

\section{Latar dan Unsur Fiksi yang Lain}

Pembicaraan di atas sebenarnya telah menunjukkan betapa eratnya kaitan latar dengan unsur-unsur fiksi yang lain. Latar sebuah karya yang sekadar berupa penyebutan tempat, waktu, dan hubungan sosial tertentu secara umum, artinya bersifat netral, pada umumnya tidak banyak berperanan dalam pengembangan cerita secara keseluruhan. Hal itu juga berarti bahwa latar tersebut kurang berpengaruh terhadap unsur-unsur fiksi yang lain, khususnya plot dan tokoh. Sebaliknya, latar yang mendapat penekanan, yang dilengkapi dengan sifatsifat khasnya, akan sangat memengaruhi dalam hal pemlotan dan penokohan. karenanya juga keseluruhan cerita. Perbedaan latar baik yang menyangkut hubungan tempat, waktu, maupun sosial, 
menuntut adanya perbedaan pemplotan dan penokohan.

Latar dengan penokohan mempunyai hubungan yang erat dan bersifat timbal balik. Sifat-sifat latar terutama latar spiritual, dalam banyak hal, akan memengaruhi sifat-sifat tokoh. Bahkan, barangkali tidak berlebihan jika dikatakan bahwa karakter seseorang akan dibentuk oleh keadaan latarnya. Hal ini akan tercermin, misalnya sifat-sifat umum orang kota. Cara berpikir dan bersikap orang desa berbeda dengan orang kota. Adanya perbedaan tradisi, konvensi, keadaan sosial, dan lain-lain yang menciri tempattempat tertentu, langsung atau tidak langsung, akan berpengaruh kepada penduduk, dan karenanya juga kepada tokoh cerita. Di pihak lain, juga dapat dikatakan bahwa sifat-sifat dan tingkah laku tertentu yang ditunjukkan oleh seorang tokoh mencerminkan dari mana dia berasal. Jadi, ia akan mencerminkan latar.

\section{Latar atau Setting}

Latar atau setting adalah segala keterangan, petunjuk, pengacuan yang berkaitan dengan waktu, ruang, suasana, dan situasi terjadinya peristiwa dalam cerita. Latar dapat dibedakan ke dalam empat unsur pokok:

a. Latar Tempat yaitu mengacu pada lokasi terjadinya suatu peristiwa berlangsung. Sebagai contoh dalam cerpen dan dalam novel, tempat berlangsungnya cerita bisa lebih dari satu. Dalam novel "Ketika Cinta Bertasbih" misalnya tempat berlangsungnya cerita ada di beberapa tempat seperti Alexandria (Mesir), Kediri, Jombang, dan Jakarta. b. Latar Waktu yaitu berhubungan dengan masalah "kapan" terjadinya peristiwa-peristiwa dalam cerita itu. Dengan demikian, ada latar waktu siang hari, malam hari, seminggu yang lalu, Maret 2014, suatu malam diakhir bulan april, dan sebagainya. Sama seperti latar tempat, latar waktu juga sering disajikan secara tersembunyi. Untuk itu, penganalisis harus pandaipandai menemukan ciri-ciri yang menunjukkan latar waktu tersebut.

c. Latar Suasana yaitu keadaan yang ada di sekitar terjadinya peristiwa dalam cerita misalnya, sunyi, mencekam, menegangkan, menakutkan, haru, sedih, gembira, cemas dan sebagainya. Dalam cerita suasana dapat ditemukan lebih dari satu macam dan kadangkadang juga tersembunyi.

d. Latar Sosial yaitu mengacu pada halhal yang berhubungan dengan perilaku sosial masyarakat disuatu tempat yang diceritakan dalam karya fiksi. Latar sosial bisa mencakup kebiasaan hidup, adat istiadat, tradisi, keyakinan, pandangan hidup, cara berpikir, dan bersikap serta status sosial.

\section{Unsur Latar}

Unsur latar dapat dibedakan kedalam tiga unsur pokok, yaitu tempat, waktu, dan sosial budaya. Walau masingmasing menawarkan pemasalahan yang berbeda dan dapat dibicarakan secara sendiri, ketiga unsur itu pada kenyataannya saling berkaitan dan saling memengaruhi satu dengan yang lainnya. Jadi, pembicaraan secara terpisah hanya besifat teknis dan untuk memudahkannya saja.

\section{Latar Tempat}

Latar tempat menunjuk pada lokasi terjadinya peristiwa yang diceritakan 
dalam sebuah karya fiksi. Unsur tempat yang dipergunakan mungkin berupa tempat-tempat dengan nama tertentu, inisial tertentu, mungkin lokasi tertentu tanpa nama jelas. Tempat-tempat yang bernama adalah tempat yang dijumpai dalam dunia nyata, misalnya Magelang, Yogyakarta, Juranggede, Cemarajajar, Kramat, Grojogan, dan lain-lain yang terdapat di dalam Burung-burung Manyar.

Tempat dengan inisial tertentu, biasanya berupa huruf awal (kapital) nama suatu tempat, juga meyarankan pada tempat tertentu, tetapi pembaca harus memperkirakan sendiri, misalnya kota $\mathrm{M}$, $\mathrm{S}$, T, dan desa B, seperti digunakan dalam Bawuk. Latar tempat yang tanpa nama yang jelas biasanya berupa penyebutan jenis dan sifat umum tempat-tempat tertentu, misalnya desa, sungai, jalan, hutan, kota kecamata, dan sebagainya.

\section{Latar Waktu}

Latar waktu berhubungan dengan masalah "kapan" terjadinya peristiwaperistiwa yang diceritakan dalam sebuah karya fiksi. Masalah "kapan" tersebut biasanya dihubugkan dengan waktu faktual, waktu yang ada kaitannya atau dapat dikaitkan dengan peristiwa sejarah. Pengetahuan dan persepsi pembaca terhadap waktu sejarah itu kemudian dipergunakan untuk mencoba masuk ke dalam suasana cerita. Pembaca berusaha memahami dan menikmati cerita berdasarkan acuan waktu yang diketahuinya yang berasal dari luar cerita yang bersangkutan. Adanya persamaan perkembangan dan atau kesejalanan waktu tersebut juga dimanfaatkan untuk mengesani pembaca seolah-olah cerita itu sebagai sungguh-sungguh ada dan terjadi.

\section{Latar Sosial-Budaya}

Latar sosial-budaya menunjuk pada hal-hal yang berhubungan dengan perilaku kehidupan sosial masyarakat disuatu tempat yang diceritakan dalam sebuah karya fiksi. Tata cara kehidupan sosial masyarakat mencakup berbagai masalah dalam lingkup yang cukup kompleks. Ia dapat berupa kebiasaan hidup, adat istiadat, tradisi, keyakinan, pandangan hidup, cara berpikir dan bersikap, dan lainlain yang tergolong latar spiritual seperti dikemukakan sebelumnya. Di samping itu, latar sosial-budaya juga berhubungan dengan status sosial tokoh yang bersangkutan, misalnya rendah, menengah, atau atas.

\section{Fungsi latar}

Fungsi dari latar sendiri yaitu untuk memberikan suatu gambaran yang jelas supaya peristiwa-peristiwa yang terjadi pada suatu karya sastra benar-benar terjadi atau memberikan informasi yang jelas mengenai situasi didalam sebuah cerita. Peristiwa konkret dan latar seolah-olah pernah terjadi dengan memberikan gambaran yang rinci mengenai aktivitas tokoh cerita. Dapat dilihat pada aktivitas petani karet, keadaan suatu tempat, pelaksanaan kebiasaan masyarakat dalam lingkungan sosial kultural tertentu, novel ini dapat dapat membuat kesan realistik yang terucap secara konseptual dan abstrak melalui bahasa menjadi sebuah cerita yang konkret yang seakan dapat dilihat, disentuh, dan dialami secara langsung oleh pembaca. Latar semacam itu dapat membuat persoalan atau tema abstrak menjadi sebuah dunia pengalaman yang realistik.

Karya sastra dapat membentuk kepribadian karena didalamnya memuat amanat tentang moral, mengembangkan imajinasi dan kreativitas siswa. Pembelajaran sastra disekolah, khususnya 
cerpen, bertujuan untuk menanamkan, menumbuhkan, dan mengembangkan kepekaan siswa terhadap masalah-masalah dunia, pengenalan dan rasa hormat terhadap tata nilai, baik dalam konteks individu maupun sosial, yang kesemua itu sangat relevan dengan muatan yang terdapat dalam kurikulum pendidikan karakter pada saat ini.

\section{PENUTUP}

Untuk membuat latar belakang yang baik dan benar, penulis harus memperhatikan beberapa poin penting yang harus ada dan diperhatikan dalam membuat suatu latar belakang dalam karya tulis. Di bawah ini adalah beberapa hal yang harus diperhatikan dan harus ada dalam penulisan latar belakang.

Dalam penulisan latar belakang harus ada kondisi baik atau ada sesuatu yang diharapkan baik dalam permasalahan khusus ,maupun permasalahan umum. Kondisi baik. tersebut harus dilampirkan didalam visi misi yang ingin diraih penulis karya tulis tersebut. Dalam penulisan latar belang, kondisi aktual yang pada saat itu terjadi harus disertakan juga. Biasanya kondisi aktual tersebut menjelaskan kondisi yang sedang terjadi dalam suatu masyarakat dan sedang dibahas. Dalam penulisan latar belakang harus menemukan jalan keluar suatu masalah atau solusi dari permasalahan yang diangkat.

\section{DAFTAR PUSTAKA}

Muliadi, 2017. Telaah Prosa: Sebuah Terapan. Makassar: De La Macca.

Nurgiyanto Burhan, 2015. Teori Pengkajian Fiksi. Yogyakarta: Gadjah Mada University Press.

Mansyur, Umar. 2016. Pemanfaatan Nilai kejujuran dalam Cerpen sebagai Bahan Ajar Berbasis Pendidikan Karakter. In Mengais Karakter dalam Sastra: HISKI Makassar (pp. 330-339). https://doi.org/10.17605/OSF.IO/Z4T3Y

Mansyur, Uma. 2018. Kiat dan Teknik Penulisan Skripsi bagi Mahasiswa. INA-Rxiv. https://doi.org/10.31227/osf.io/juds7

Trirahayu. 2013. http://trirahayu57.blogspot.com/2013/12/makalah-analisis-unsur-intrinsikprosa.html?m=1. diakses pada tanggal 21 oktober 2018 .

Yuyunari. 2015. https://yuyunari.wordpress.com/2015/01/05/makalah-telaah-prosa-mengenaiunsur-instrinsik-karya-sastra/diakses pada tanggal 23 oktober 2018. 